\title{
Economy and status of Neolithic to Early Bronze age sites in the Southern Caucasus during the 6th-3rd mill. BCE: The evidence from ground stone tools
}

\author{
Caroline Hamon \\ CNRS, Permanent Researcher, UMR 8215 Trajectoires, Maison de l'archéologie, 21 allée de l'Université 92023 \\ Nanterre cedex, France. Email: caroline.hamon@cnrs.fr
}

\begin{abstract}
:
In the Southern Caucasus, the evolution of the Neolithic to Bronze age (6th-3rd millenia BCE) economies is often investigated through the prism of adaptation to constrasted landscapes and environments (arid plain, high moutains, subtropical western coasts) and strategies of natural resource exploitation. This overview of the main technological and functional characteristics of ground stone tools from about 20 sites in the Kura Valley (Georgia, Azerbaijan) contributes to the discussion surrounding these questions. After an overview of the evolution of the grinding equipment and stone tool manufacture within a long term perspective, from the Late Neoliothic to the Early Bronze Age, several issues are adressed. The composition of the macrolithic toolkit is a key issue when discussing the importance of agriculture versus pastoralism in the economy of these populations, which evolved in different regional and environmental contexts. Its management also contributes to our understanding of the degree of sedentarity versus mobility of the populations. Finally, we discuss how the technical evolution of the macrolithic toolkit reflects the principal global changes occurring during this long period of time (neolithisation, emergence of metallurgy, and the mining phenomenon) and their cultural meaning. Our initial results underline the significance of some implements as cultural markers, and also contribute to defining the common cultural background and regional specificities within the South Caucasus region.
\end{abstract}

Keywords: economy; Caucasus; macrolithic implements; Neolithic; Bronze Age

\section{Introduction}

The Southern Caucasus is located at the geographical and cultural crossroads between Europe and Asia. It occupies a territory of some $800 \mathrm{~km}^{2}$ between the Black Sea to the west and the Caspian Sea to the east. Due to its complex tectonic history, the region is organised around two main mountain ranges: to the north the Greater Caucasus range constitutes a natural border which reaches heights of up to 5000 meters, while to the south the volcanic plateaus of the Lesser Caucasus occupy a large central part of the region. Two main rivers structure the hydrographic and circulation network, with the Kura between the Greater and

Journal of Lithic Studies (2020) vol. 7, nr. 3, 18 p.

DOI: https://doi.org/10.2218/jls.3086

Published by the School of History, Classics and Archaeology, University of Edinburgh ISSN: 2055-0472. URL: http://journals.ed.ac.uk/lithicstudies/

Except where otherwise noted, this work is licensed under a CC BY 4.0 licence.

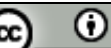


Lesser Caucasus, and the Araxe which constitutes the southern border of the region. This particular relief and climatic pattern of the Southern Caucasus explains the mosaic of landscapes coexisting in this small area (Figure 1). To the west, a subtropical climate dominates the Black Sea shores and the Colchida Plain, while a mountainous climate characterises the Greater and Lesser Caucasus. Semi-arid plains and steppes occupy the middle Kura and Araxe Valleys, at the confluence of which a salty environment has developed. This very particular geographical context explains why the first agricultural economies in the region ( $6^{\text {th }}$ to $3^{\text {rd }}$ millennia BCE) (Nishiaki et al. 2015) are often examined through the prism of contrasted landscapes and environments, and the exploitation of rich mineral and vegetal resources. Through the technological and use-wear analysis of a large sample of macrolithic tools from the Kura Valley, our goal is to identify the solutions adopted by Caucasian populations at several key moments of their history, from the emergence of agriculture to the development of metallurgy.

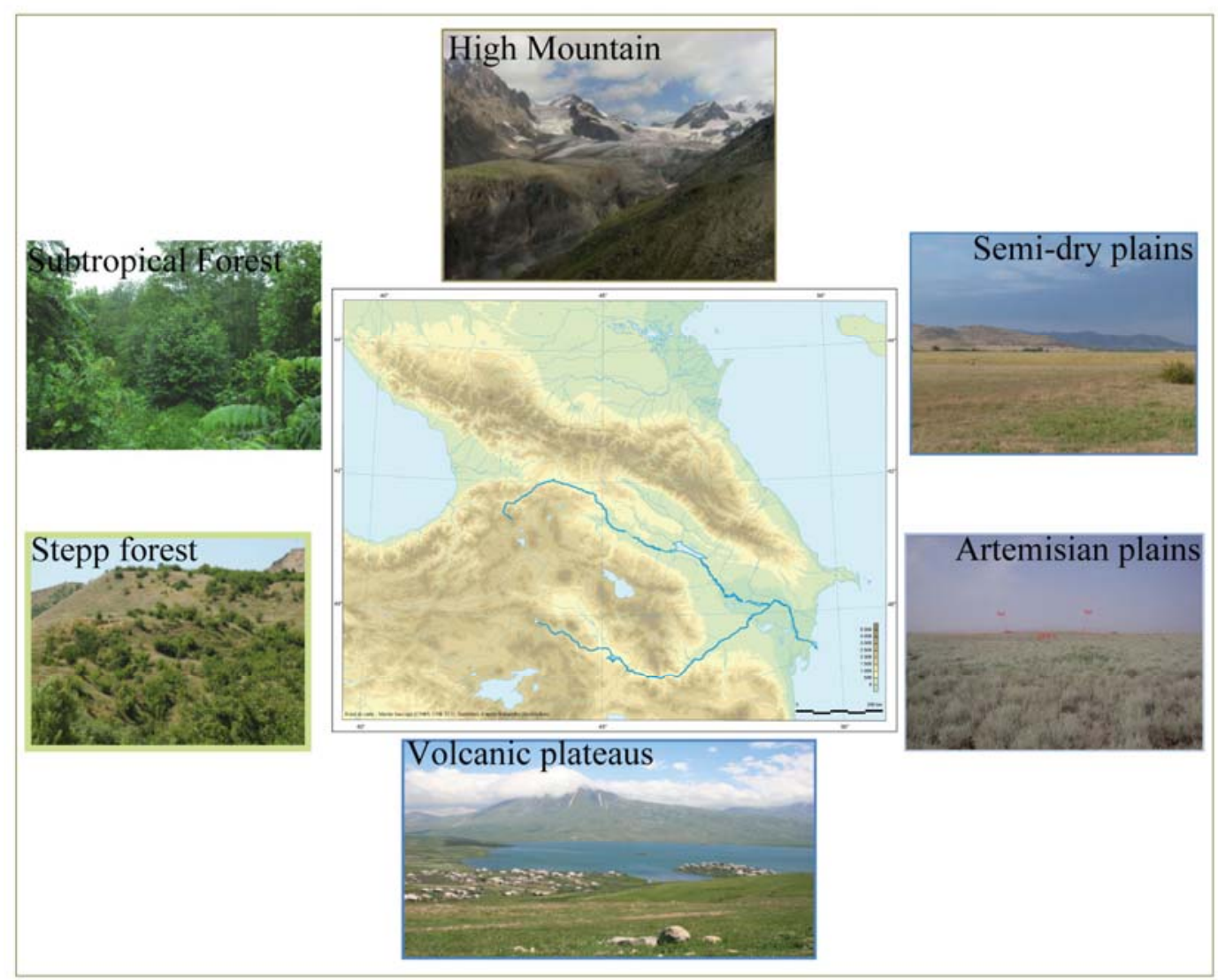

Figure 1. The different landscapes and environments in South Caucasus: to the North high mountainous landscapes, to the South volcanic plateaus, to the West subtropical forests and step forests on the piedmont, to the East semi-dry and artemisian plains.

\section{Materials and methods}

Our study is based on raw material, technological and use-wear analyses (at low and high magnification) of the macrolithic assemblages from a sample of about 20 sites excavated in the Kura valley and neighbouring regions of Georgia (Figure 2). The sites are dated to the period spanning the Late Neolithic and Early Bronze Age (e.g., Kushnareva 1997; Lyonnet 2007; Sagona 2014). 
Comparisons are drawn with macrolithic series from Armenia, Azerbaijan and Russia. The macrolithic tools from seven Late Neolithic sites have been studied: the four sites of the Shulaveri Group, together with Khramis Didi and Aruchlo in Kwemo-Kartli (Hamon 2008a; Hansen et al. 2013), and Mentesh Tepe in the middle Kura basin (Lyonnet et al. 2012). For the Chalcolithic, macrolithic series from different chrono-cultural contexts are compared: three sites from the Aragvi Valley, the major sites of Sioni and Bereekldebi in Georgia, implements from the two chalcolithic layers of Mentesh Tepe (Lyonnet et al. 2012), with the assemblage of a Majkop settlement from the North-western Caucasus as a comparison (Hamon 2007). Finally, we use three sites belonging to the Kuro-Araxe culture of the middle Kura valley to illustrate the Bronze Age: Mentesh tepe (Azerbaijan) and six sites from Georgia (Abasnorevi 1 and 3, Davati, Kwartzrelebi Ortchosani, Samschwilde), which are compared to the mining assemblage from Sakdrisi (Georgia) (Stöllner et al. 2014). Technological analysis was conducted on all of the series, while use-wear analysis was only carried out on some of the assemblages (Shulaveri group, Mentesh Tepe, Majkop assemblage), using published experimental referential (Dubreuil 2004; Hamon 2008b).

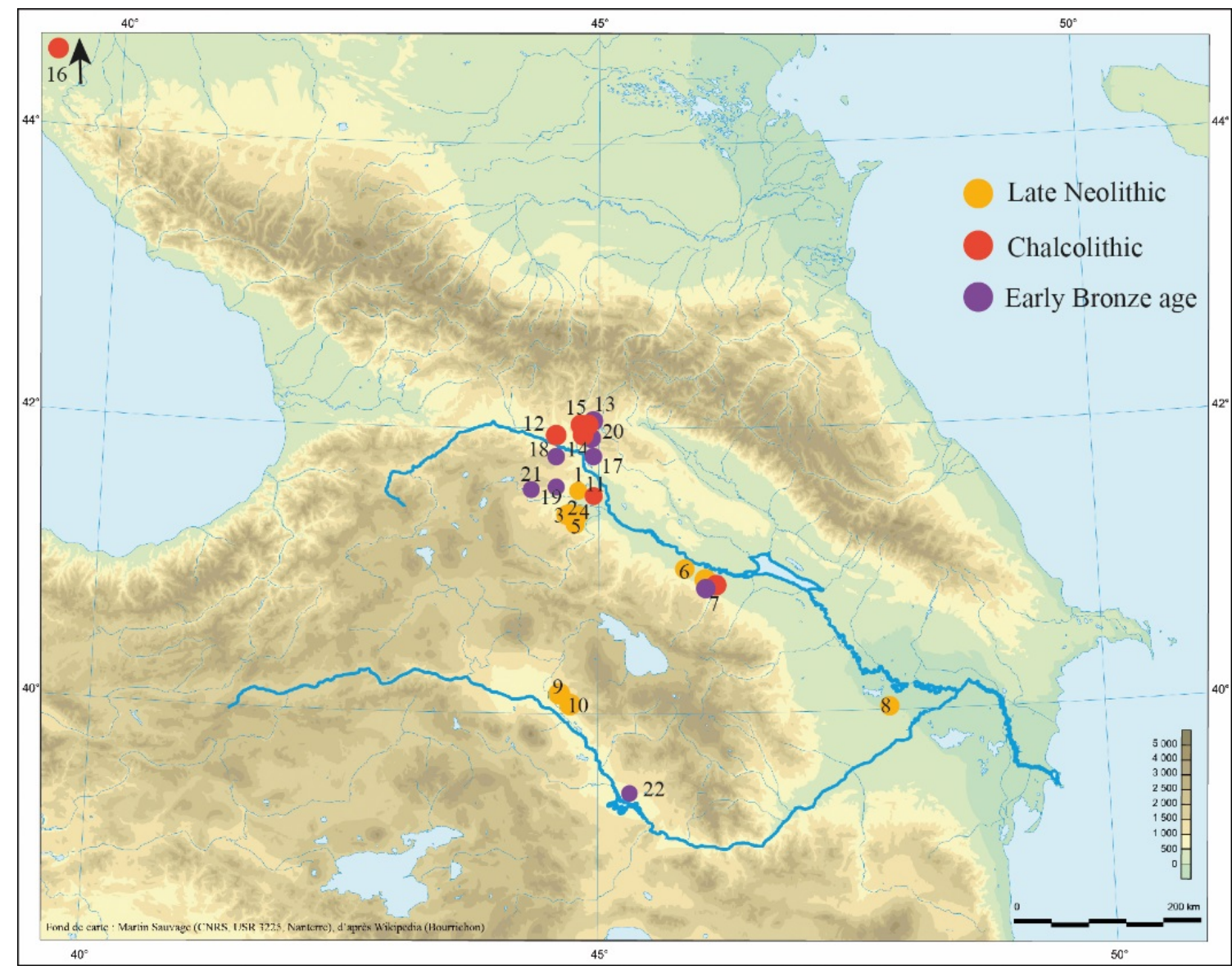

Figure 2. Localization map of the main sites mentioned in this study. Neolithic - Georgia: 1. Aruchlo, 2. Shulaveris gora, 3. Imiris gora, 4.Gadachrili gora, 5. Chramis Didi gora - Azerbaijan: 6. Goy Tepe, 7. Mentesh Tepe, 8. Kamil Tepe and Mil plain sites 4 \& 5 - Armenia: 9. Aratashen, 10. Akhnashen. Chalcolithic - Georgia: 11. Sioni, 12. Bereekldebi, 13. Abasnorevi, 14. Chinti, 15. Zhinvali, Russia : 16. Majkop. Early Bronze Age Georgia: 17, Ortchosani, 18. Kwartzrelebi, 19. Samschwilde; 20. Davati; 21. Sakdrisi; Azerbaïdjan: 22. Duzdagi. 


\section{Results}

\subsection{The Neolithic contexts (5900-5300 BCE)}

\subsubsection{Cultural background}

The emergence and origin of the Neolithic in the South Caucasus is still the subject of much debate. The first evidence for possible Early Neolithic settlements is dated to between the $9^{\text {th }}$ and $7^{\text {th }}$ millennia BCE (see review in Chataigner et al. 2014). They include sites in Dagestan, as well as in the western part of Georgia (Black Sea coast, Kvirila Basin, Imeretie) (see Niebieridze 1986) and Armenia (Kasakh River) (Arimura et al. 2010). Here, the lithics appear to indicate a possible transition between the Mesolithic and Neolithic, although the existence of domestic fauna and plants remains unclear. The so-called Late Neolithic emerged in the South Caucasus at the turn of the 6th millennium BCE in the Kura and Araxe Basins (Nishiaki et al. 2015). Two main regions, the Ararat Plain and the middle Kura Basin, witnessed the development of the Akhnashen-Shulaveri-Shomu culture up to $5300 \mathrm{BCE}$. This culture is characterised by a full agricultural economy, the production of ceramics and of polished stone tools (adzes, axes), evidence for which is found on stratified settlements characterised by connected circular structures of various sizes, together with "courtyards" used as circulation or waste disposal areas (Badalyan et al. 2010; Dzhavakhishvili 1973; Guliyev \& Nishiaki 2014; Hamon et al. 2016; Lyonnet et al. 2012). To the south-east, the Mil Plain culture presents quite a different pattern, especially in the organisation of its architecture, and reveals clear influences from the neighbouring Middle Eastern cultures (Lyonnet et al. 2012). The general pattern gives the impression of permanent, densely occupied settlements, with a strong agricultural identity, sharing a more or less common cultural background and influences from neighbouring cultures.

\subsubsection{Macrolithic equipment}

In this context, macrolithic implements are used in a wide range of activities, including food processing and craft activities (Hamon 2008a). On most of the sites, the raw material supply is generally organised around the exploitation of alluvial deposits from local riverbeds. Vesicular and dense basalts are selected for grinding actions, while more diverse and dense rocks are preferred for pounding and hammering actions. Pumice, sandstones, limestones and tuff are used for polishing and abrading (Figure 3).

In fact, a wide range of grinding systems characterises the Late Neolithic sites of the Kura region (Figure 4). Back-and-forth as well as multidirectional or circular motions were used to process a wide range of materials, including cereals and plants for consumption, or minerals for pigment. Different types of blanks and active surfaces can be defined and there exists a wide range of sizes. Saddle-shaped or flat querns made from quadrangular blanks were used in conjunction with elongated, massive grinders or loaf-shaped grinders. They coexisted with narrow, concave, ovoid grinding slabs, used in a circular motion with short handstones or, alternatively, with overlapping grinders. All of these forms are also documented in the Near East (Wright 1992). A chronological evolution of grinding tool types has been proposed for the Shulaveri group: in this case we see a development from short grinders associated to ovoid concave querns with distal or peripheral edges at the beginning of the sequence, to flat grinders with plano-concave querns without edges at the end of the sequence (Hamon 2008a). The intensity of the use-wear traces and the high distortion of the tool surfaces, strongly suggests long duration of use on permanent settlements which were occupied over several years. The frequency of tool breakages evokes rather deliberate acts, as no taphonomical, contextual, functional or biographical elements explains such regularity of the breakage action, and its close relationship only with lower grinding tools at the exception 
of any other categories of macrolithic implements. They could be possibly linked to the abandonment of the habitation or the death of the owner of the tools. The tools also suggest that a wide variety of cereal treatments and preparations may have been carried out on Neolithic settlements. The significant number of tools reused for the processing of ochre into powder is also striking (grinders, crushers, slabs and basin querns), although the final destination of the ochre is unclear (decoration of buildings, clothing, skin or ornaments, technical treatment).

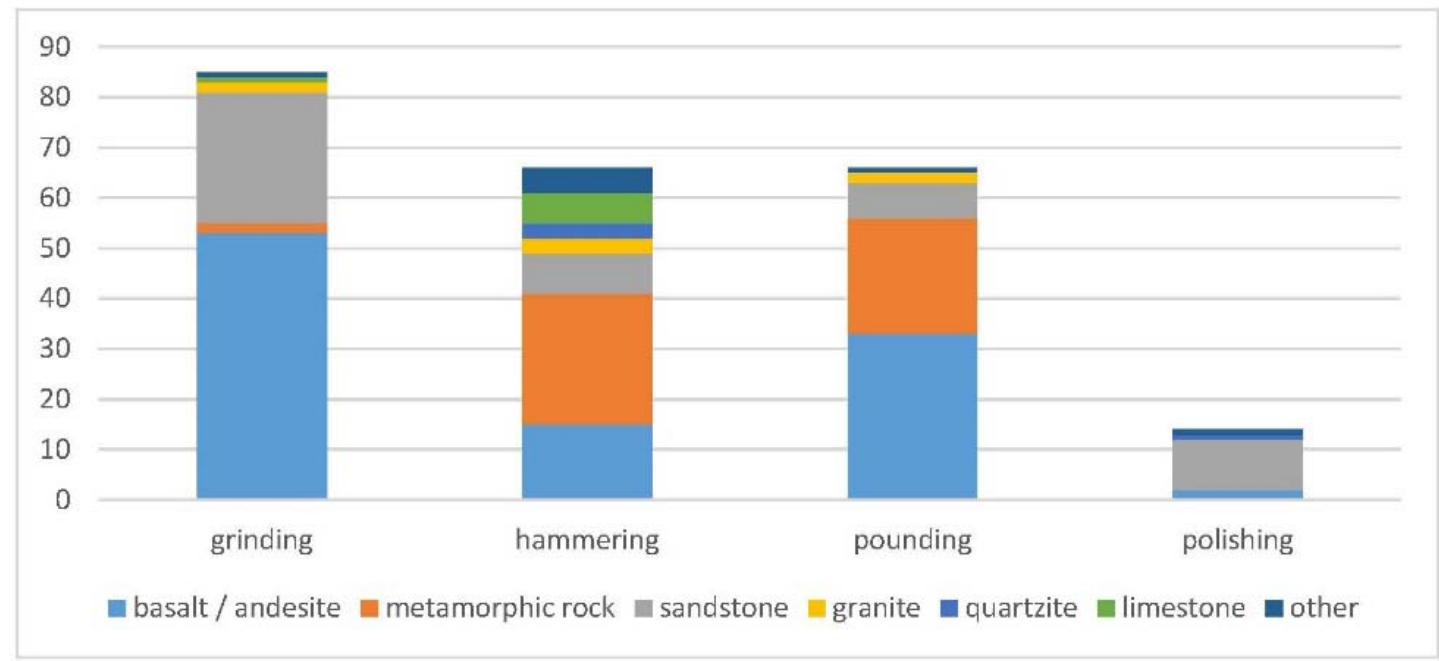

Figure 3. Selection of types of rock by great activities among Shulaveri-Shomu macrolithic tools (after data in Hamon 2008a).

In addition to grinding tools, a large variety of pounding and crushing implements make up the series (Figure 5). A small number of basin slabs and massive mortars of granite and basalt, with circular cavities up to $15 \mathrm{~cm}$ deep, are known, while some querns were reused as lower crushing tools. Numerous tronconical to cylindrical pestles, of different sizes, made from volcanic rocks, make up most of the assemblages; pestles in pumice were also used on some sites (Hansen et al. 2013), as well as more opportunistic pestles. They coexist with crushing tools, also used as handstones. In Kwemo-Kartli, a particular type of circular grinding slab features two opposite active surfaces and bifacial flaking on the sides (Hamon 2008a, Kiguradze 1986).

Among the percussion tools, a small number of anvils, made of various rock types, feature convex surfaces with rare percussion impacts. At least six types of hammerstones have been defined. A large number of them, made from dense volcanic cobbles, are more intensively used on their distal ends and edges. Another frequently found tool type are chopping tools, which were shaped by unifacial or bifacial flaking to create an edge then used in percussion as evidenced by impacts and microflaking.

In the Kura valley, rare hand-polishers are mostly made from sandstones and limestones and feature small, concave surfaces. Some small prismatic polishers, made from metamorphic rocks, display pronounced concavity. Taken together, this evidence suggests relatively low investment in the shaping of bone tools and ornaments.

Several frequently found perforated discs or ovoid cobbles are interpreted as spindle whorls. Different kinds of perforated mace heads, ranging from simple spheres to more complex decorated or carved morphologies, are also present. Finally, one should note the 
presence of limestone vessels in the later layers of occupation of the Shulaveri-Shomu sites, especially in Chramis Didi gora and Mentesh tepe (Hamon 2008a; Lyonnet et al. 2012).
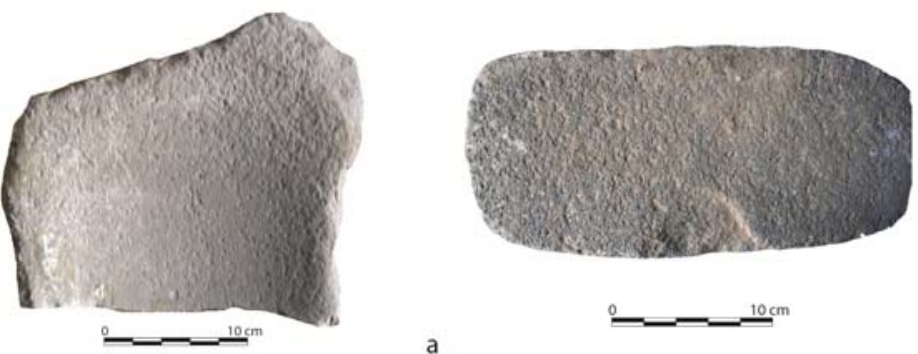

a

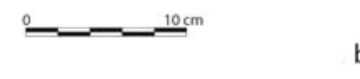

b
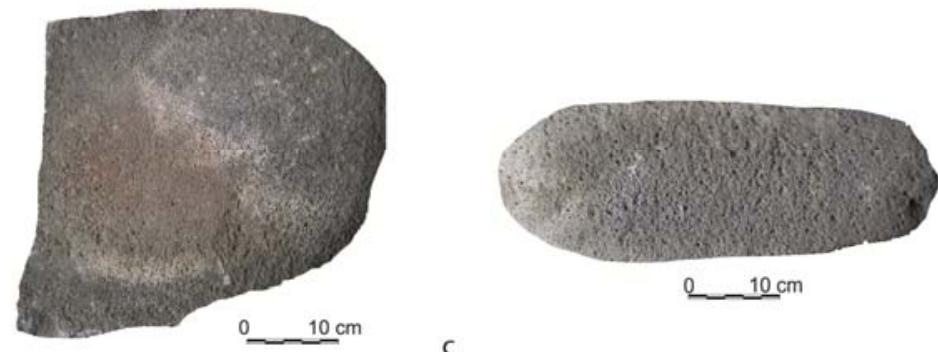

c
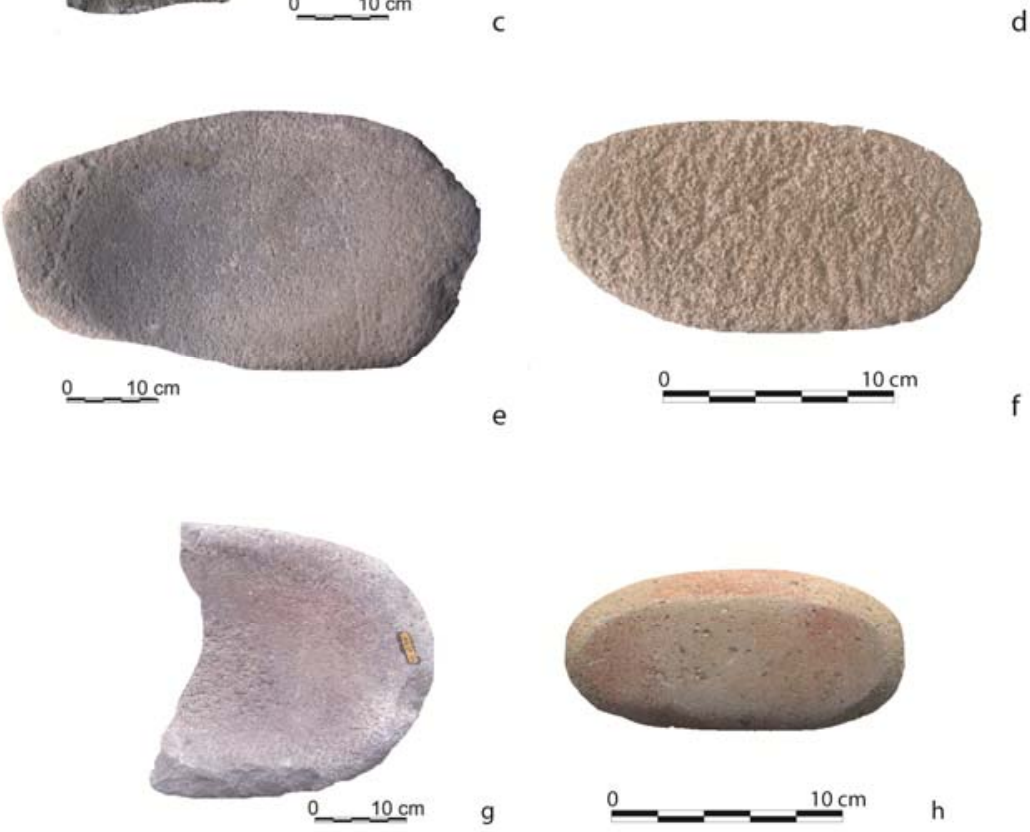

g

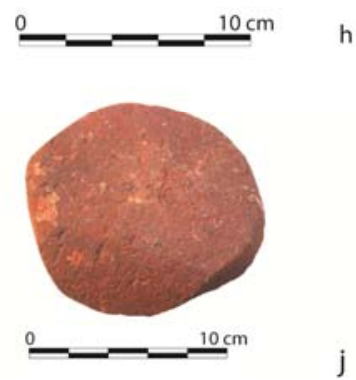

Figure 4. Late Neolithic from the middle Kura valley (Shulaveri group). Different grinding tools types: a. quadrangular concave quern used in back-and-forth motion (Shulaveri); b. loaf-shaped grinder (Imiris); c. flat ovoid quern (Imiris); d. narrow elongated grinder (Imiris); e. ovoid grinding slab (Imiris); f. short grinder (Shulaveri), h. ochre processing reused grinding slab (Shulaveri); i. handstones used for ochre fine grinding (Chramis Didi gora); j. grinding slab (Imiris); k. abrader ochre fragment (Chramis Didi gora) (photographs by C. Hamon). 

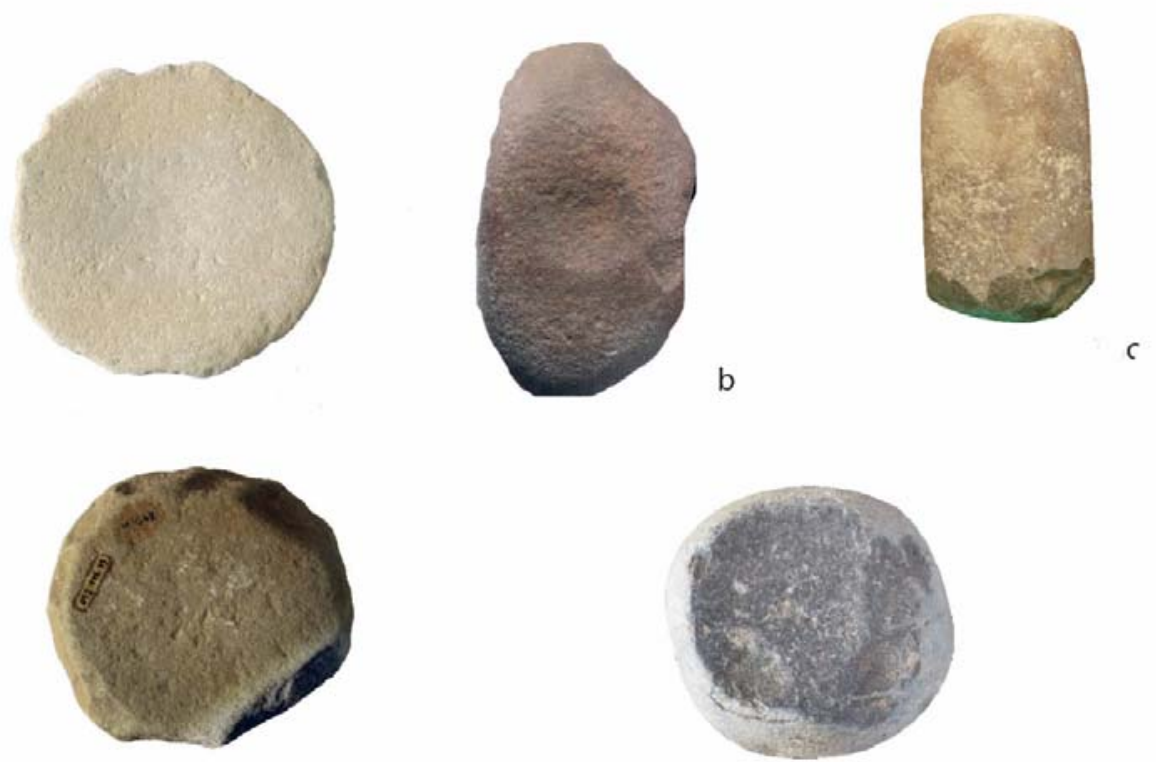

$\underline{0}$ $10 \mathrm{~cm}$

a
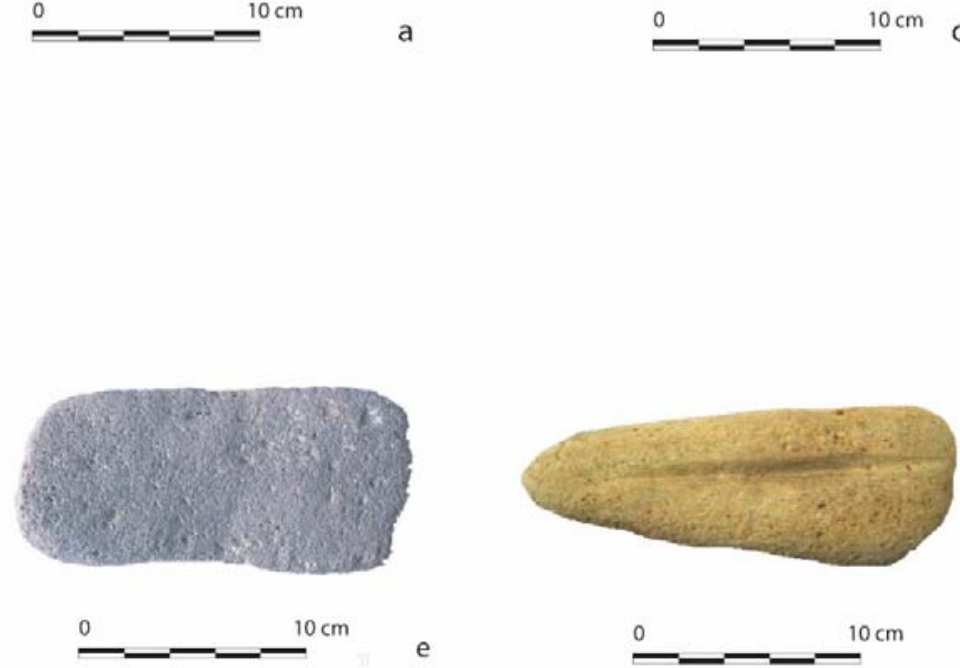

e

0

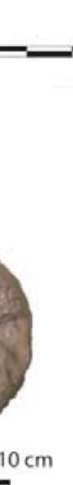

g

Figure 5. Late Neolithic percussing and abrading tool types from the middle Kura valley a. Circular grinding slab of "Imiris" type; b. crushing tool (Shulaveris gora); c. Pestle (Mentesh tepe); d. Hammerstone (Mentesh tepe); e. abrader-pestle in pumice (Shulaveris gora); f. polisher (Imiris gora); g. perforated items (Imiris gora) (photographs by C. Hamon). 


\subsubsection{Interpretation}

The macrolithic equipment found on the Late Neolithic sites (6th millennium BCE) in the South Caucasus reveals a very complete toolkit, with evidence for intensive daily food preparation and diversified craft activities associated with domestic settlements. Several clues relating to the management of the raw material, the intensity of use and the reuse cycles of the grinding tools indicate that these tools had a relatively long life span and also suggest a degree of settlement permanency linked to intensive agricultural activities. They also lend support to the hypothesis of a common and rather homogeneous cultural background for the Ararat Plain and middle Kura Basin. Both regions share common grinding tool types (Hamon 2008a; Badalyan et al. 2010), numerous pestles, crushing tools and mortars as well as hammerstones made from volcanic rocks, and they also both reveal evidence for intensive processing of ochre. Next to this standard toolkit, some specific tool types show varying features, which can be interpreted as functional particularities (circular grinding slabs of Imiris type), or regional cultural variants (grooved polishers, maceheads). For example, in the Ararat Plain, a large series of abraders, made from pumice, has been recognised, which, together with grooved polishers, constitute a regional specificity. These transverse grooved polishers made from ophiocalcite show close parallels with middle Halaf sites, but also with sites in eastern Mesopotamia and the Zagros (Badalyan et al. 2007; 2010). In fact, these implements indicate close relationships with the Anatolian and northern Mesopotamian worlds and contribute to our understanding of the origins of the neolithisation of the South Caucasus area.

\subsection{The Chalcolithic contexts (4800-3500 BCE)}

\subsubsection{Cultural background}

The Chalcolithic period in the South Caucasus corresponds to a period of major shifts in the economies of these populations, with the introduction of metallurgy and the reinforcement of pastoralism and mobility throughout the region. The appearance and coexistence of different cultural groups, occupying much smaller areas, is accompanied by an evolution and a diversification of the ecological contexts occupied, of types of sites and of related activities (Sagona 2014). In the southern Caucasus valleys, the Early Chalcolithic is documented by the latest occupation layers of the Late Neolithic tells, with the same tradition of circular mudbrick habitations existing in both periods (Kiguradze 1986; Lyonnet et al. 2012). The first half of the $5^{\text {th }}$ millennium BCE is poorly documented, but recorded evidence includes pits, hearths and light wooden structures (Mentesh phase II) (Lyonnet et al. 2012). The emergence of the Sioni culture in the middle Kura Valley (4800-4000 BCE) is principally evidenced by the presence of its characteristic ceramics on a large variety of sites (Kiguradze \& Sagona 2003). In the $4^{\text {th }}$ millennium BCE, some major open-air sites were structured around large subdivided quadrangular buildings, as at Bereekldebi (Djavakhishvili 1998), or Mentesh Tepe phase III (Lyonnet et al. 2012). Other small scale settlements in the mountain valleys of the Greater Caucasus may have been related to the circulation of ores (sites of Chinti, Jinvali and Abasnorevi in the Aragvi Valley) (Chikovani 1999). To the north, the small open-air Majkop sites (3800-3200 BCE) (Lyonnet 2007) evoke more direct relationships with specialised activities such as pastoralism. In fact, the degree of sedentarity versus mobility of Chalcolithic people of the Kura Valley was very much correlated to the environmental context in which they evolved, to the function of the sites and to their cultural background.

\subsubsection{Macrolithic equipment}

The macrolithic implements of the Chalcolithic period directly reflect these differences in status, economy and cultural background. 
Despite the diversity of the Sioni sites, a common toolkit can be defined (Figure 6). On the eponymous Sioni site, the few macrolithic tools present evoke a double phenomenon: 1) Ovoid grinding tools, made out of vesicular basalt cobbles which were shaped by fine pecking of their external surface, are reminiscent of the Shulaveri-Shomu tradition, 2) the rest of the toolkit is composed of small, very striated handstones, sharpeners as well as a series of crushing tools, which might suggest that emerging copper metallurgy played a significant role in determining the toolkit. In Bereekldebi, the assemblage suggests the following evolution: Well-shaped basalt grinding tools and volcanic hammerstones and pestles are reminiscent of the Shulaveri sphere, while the wide range of small crushing tools with deep circular cavities and sharpeners, sometimes perforated, would have taken part according to use-wear analysis in the increasing metallurgical activities of the period (Courcier et al. 2017). In Mentesh Tepe, to the south of the middle Kura Valley, there is clear continuity between the types and characteristics of macrolithic implements in the Neolithic and the Chalcolithic assemblages (Lyonnet et al. 2012), even though the Chalcolithic layers seem to be characterised by an increasing occurrence of pestles, hammerstones and grinding slabs, among the grinding equipment.

This prominence of crushing tools in the assemblages is also perceptible on all of the sites in the Aragvi Valleys; there, both lower and upper active crushing tools coexist with deep mortars and smaller mortars that could be interpreted as crucibles (Figure 7). However, on these sites most of the opportunistic grinding tools are made from large cobbles, a fact which represents a break with the Shulaveri tradition. This could be explained by a major difference in the economy of these sites, less based on cereal food procurement and turned more towards specialised activities.

To the north side of the Caucasus range, the macrolithic assemblages from the Majkop sites located on the shores of Krasnodar Lake provide interesting points of comparison concerning the economies of small open-air occupations (Hamon 2007). Grinding tools are made from cobbles of coarse conglomerates. Their varied morphologies, low investment in shaping and very low durations of use suggest that these were opportunistic tools. Two systems of circular grinding can be identified, but the classical back-and-forth motion is absent.

Use-wear analysis suggests that these implements were used for processing cereals but also mineral material (tempers, pigments). Some pestles seem to be related to food preparation. Two kinds of tools provide particularly interesting information. Circular to ovoid handstones, made of metamorphic rocks, were used in a friction gesture on a supple greasy material, such as skin: This is suggested by the surface smoothing associated with dense striations on their faces and sides. Other small ovoid cobbles present a distal distortion of their faces, together with smoothing and small striations which could be related to ceramic production (Dubreuil 2004; Hamon 2008b). This evidence reflects temporary settlements, whose economy seems to have been orientated more towards the exploitation of animal products, possibly linked to pastoral activities, rather than to cereal consumption. 


\section{Bereekldebi}

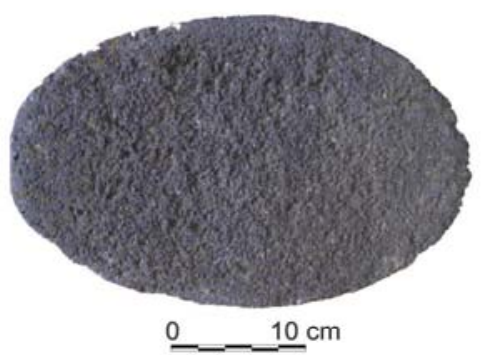

a
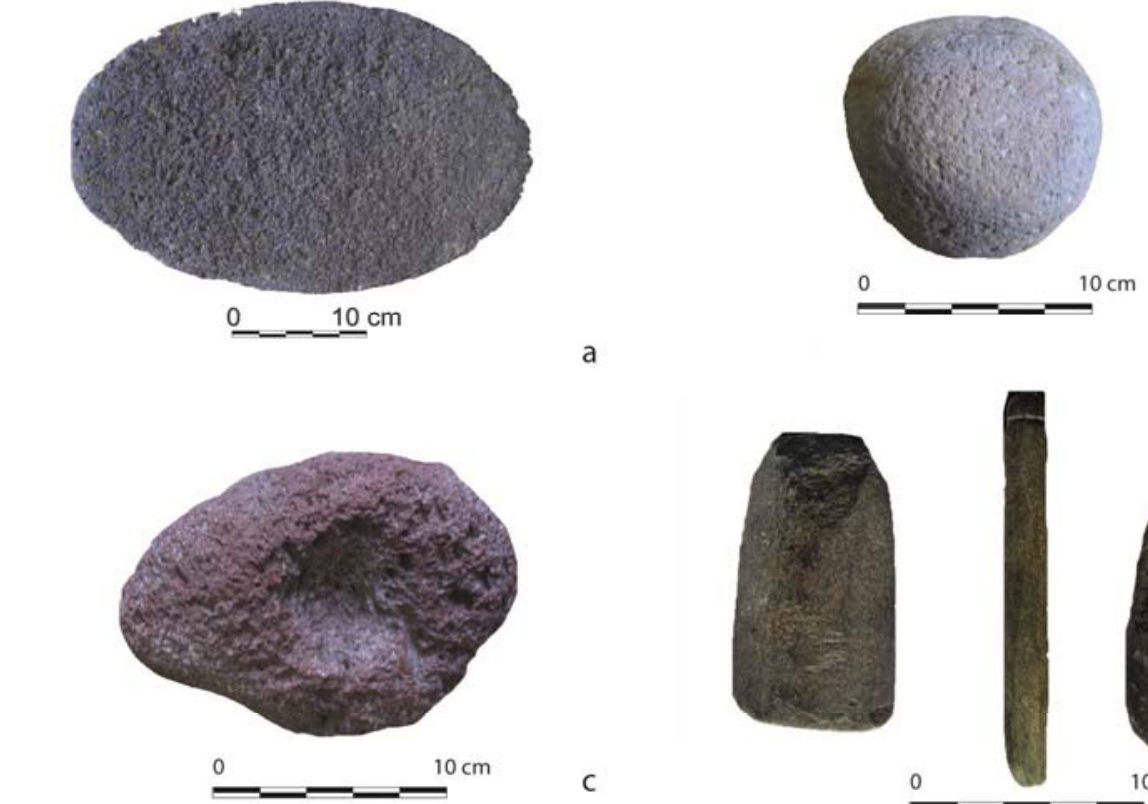

Sioni
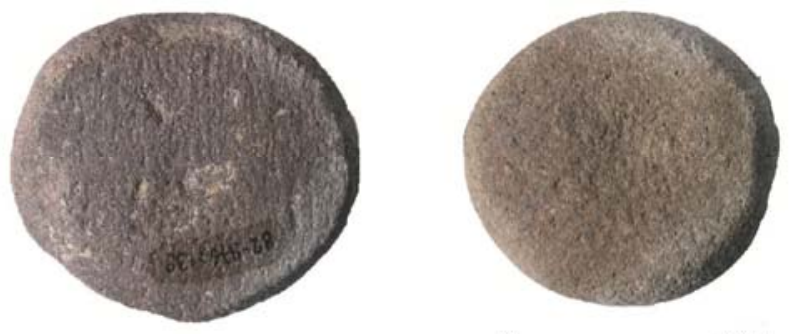

$\underline{0}$ $10 \mathrm{~cm}$
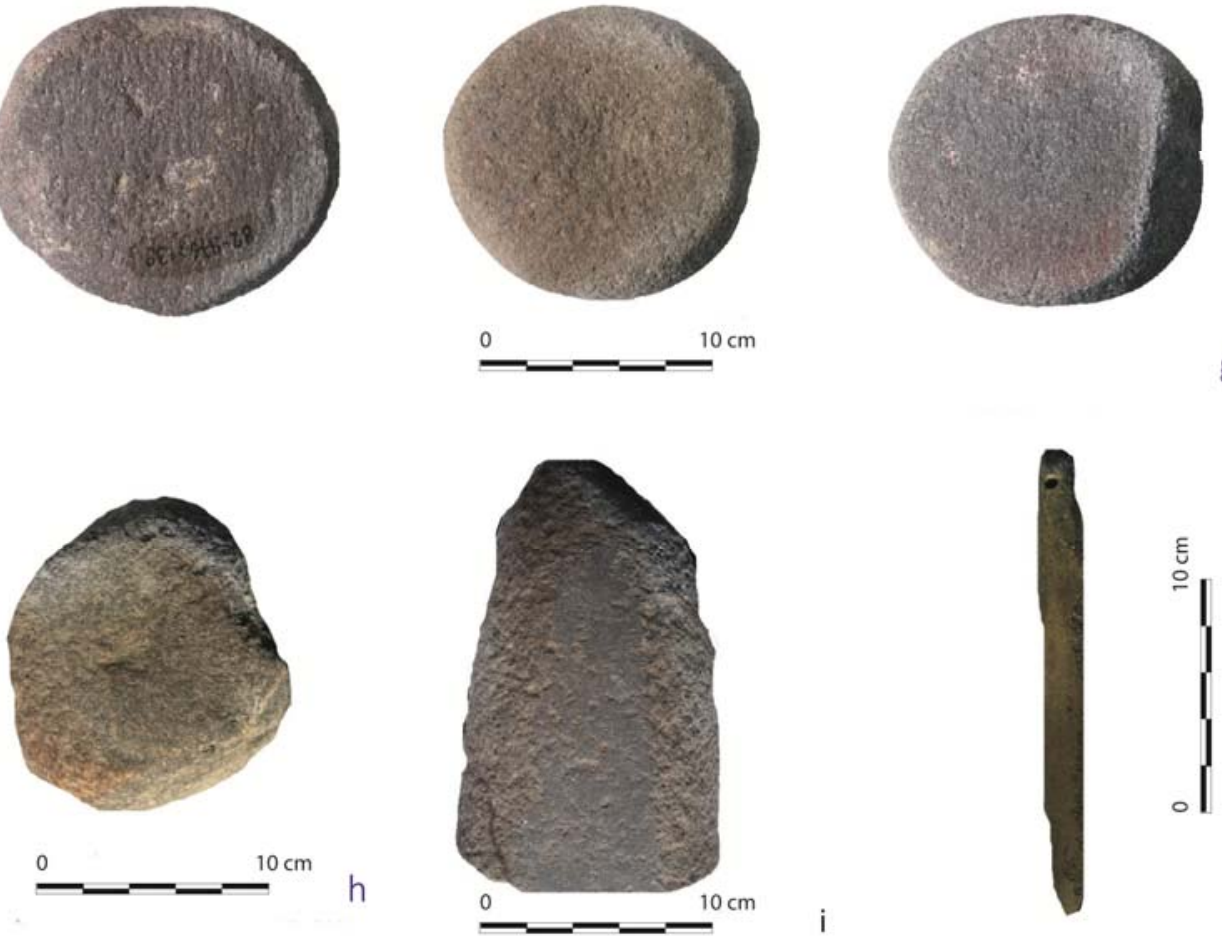

g

j

Figure 6. Chalcolithic macrolithic implements. Bereekldebi: a. grinding tool; b. small spherical grinderhammerstone; c. Crusher; d. Pestle; e. sharpener; f. burnisher. Sioni g. serie of small grinder-crusher for mineral matters processing; h. hammerstone-crusher; i. pestle; j. sharpener (photographs by C. Hamon). 


\subsubsection{Interpretation}

The macrolithic tools from Chalcolithic contexts appear altogether less diversified (mainly grinding, pounding and crushing implements) and may have been used in a reduced number of activities. In fact, the evolution perceptible in the macrolithic assemblages of the Chalcolithic period is affected by several mechanisms. The grinding tool characteristics (morphologies, technical features and function for cereal processing) from the main valley sites seem to be directly related to the Late Neolithic tradition: On these permanent sites, cereal processing still plays an important part in the economy, although the multiplication of mortars and pestles suggests an important shift in the types and techniques of plant food processing. In other ecological contexts, such as the steppes of the Northern Caucasus or the mountain valleys, the temporary nature of the settlements is more evident, especially through the reduced investment in, and duration of use of, the grinding implements. However, we suggest that the evolution of the macrolithic tools types is linked to the intensification of mineral exploitation, especially in a context of emerging metallurgy. Multiplication of crushing slabs and cobbles, together with the appearance of sharpeners, might be related at least partly to the processing of copper ores. This phenomenon would affect small secondary open air sites, but also permanent structured settlements of the Late Chalcolithic, such as Berikledeebi or Leilatepe (Akhundov 2007).

Aragvi valley

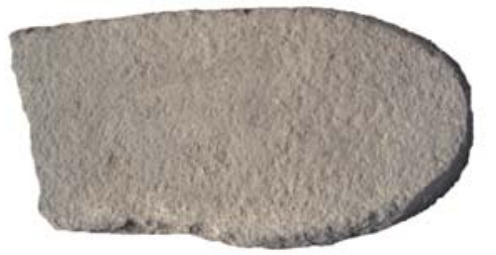

a
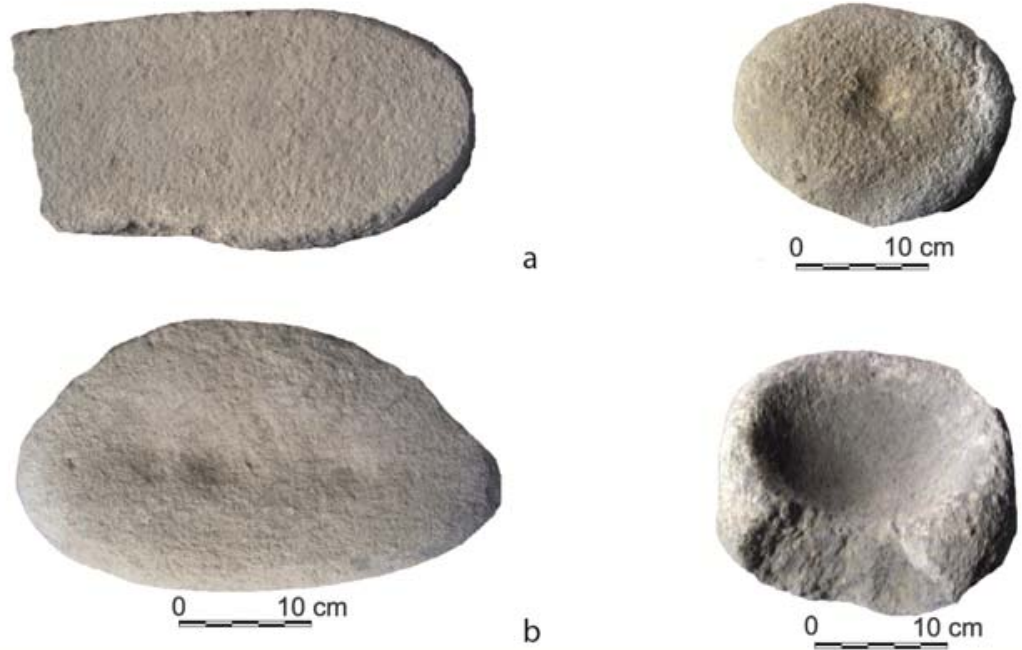

C

d

Figure 7. Chalcolithic macrolithic implements. Argavi valley: a. grinding tool on cobble (Abasnorevi, Aragvi valley); b. grinding tool used as crushing slab (Chinti); c. Crusher (Chinti); d. mortar (Chinti) (photographs by C. Hamon).

\subsection{The Bronze Age contexts (3500-2500 BCE)}

\subsubsection{Cultural background}

The early Bronze Age is represented in the South Caucasus by the Kuro-Araxe culture (e.g., Palumbi \& Chataigner 2014). This culture constitutes a clear rupture with the Late Chalcolithic. This break is evident in the ceramics and metallic products, the domestic structures (abandonment of multicellular rectangular structures) and in the burial customs (development of collective burials). In addition, increasingly intensive settlement in the mountain zones, possibly linked to specialised sheep and goat pastoralism, and the rapid spread of the Kura-Araxes "package" far beyond its initial core area (Sagona 2014), 
demonstrate the capacity of these groups to develop and maintain wide-ranging exchange networks over large territorial areas, reaching as far as the Levantine coast during the 3rd millennium BCE. While the role of ore exploitation and diffusion in the development of Kura-Araxe culture is still debated, it is clear that a wider mining phenomenon is attested in different parts of the Caucasus and for different types of resources (copper, gold, salt) during this period (Stöllner et al. 2014; Marro et al. 2010).

\subsubsection{Macrolithic equipment}

The Kura-Araxes grinding equipment illustrates a clear rupture with the previous Late Chalcolithic culture. One of the best preserved examples was found in situ in a Kura-Araxe pit at Mentesh tepe, but other examples appear to have been deposited in storage pits (Lyonnet et al. 2012). These characteristic grinding tools are made out of vesicular basalts and show a very high level of finishing by pecking. They associate massive concave querns with overlapping grinders, which were strictly used in a back-and-forth motion. These grinders are very long $(40$ to $60 \mathrm{~cm}$ ) and the ends are shaped to create a handle (Figure 8). Their active surfaces are longitudinally concave but convex to flat in width. On most of the upper and middle Kura sites, two morphologies seem to have coexisted: very narrow and elongated in Kwartzerelebi, Samschwilde, Abasnorevi or more bread-shaped as in Davati. Some ovoid to quadrangular querns show edges on one or both of their ends, such as in Ortchosani, Davati and Abasnorevi. This particular type of grinding system, though not exclusive, appears to be a chronological marker of the Kura-Araxe culture throughout the southern Caucasus. The shape and size tendency to standardisation may indicate that they were produced by specialised craftsmen, or at least by a part of the population mastering the specific know-how necessary for their production.

Along with these grinding tools, the macrolithic assemblages of settlements seems mostly limited to different types of mortars. Certain examples with a large open mouth could clearly belong to the category of stone vessels (Davati, Samschwilde), while others, featuring very small but deep cavities, are more characteristic of crushing tools (Abasnorevi, Kwartzrelebi). The respective functions of these two kinds of mortars are, for the moment, unknown.

Finally, the features of the toolkits associated with Kuro-Araxe mines must be discussed. On the copper and gold mine of Sakdrisi (Stöllner et al. 2014), thousands of opportunistic and grooved picks were used for the extraction of ores. In addition, large numbers of grinders and grinding slabs, crushing tools and mortars were used to reduce the ore into smaller fractions or powder. It is striking to note that very few mining tools have been found on the settlement sites but that similar crushing tools occur in both mining and settlement contexts: this suggests that episodes of ore processing occurred in secondary workshops within the settlements. Other Kuro-araxes tools are recorded from mining sites, such as in the Racha region (Tamazashvili 2014) or on sites further to the south. On the salt mine of Duzdagi, in Naxcivan, hundreds of very carefully-made stone hammers and picks attest the intensive exploitation of salt by the Kuro-Araxian populations of the Arax valley (Hamon 2016). On this site we see that fragments of cereal querns and grinders were removed from the nearby settlements to be reused for the processing of salt. In addition, a wide range of hammerstones were used for the shaping of the picks within secondary workshops located on the mine site. 

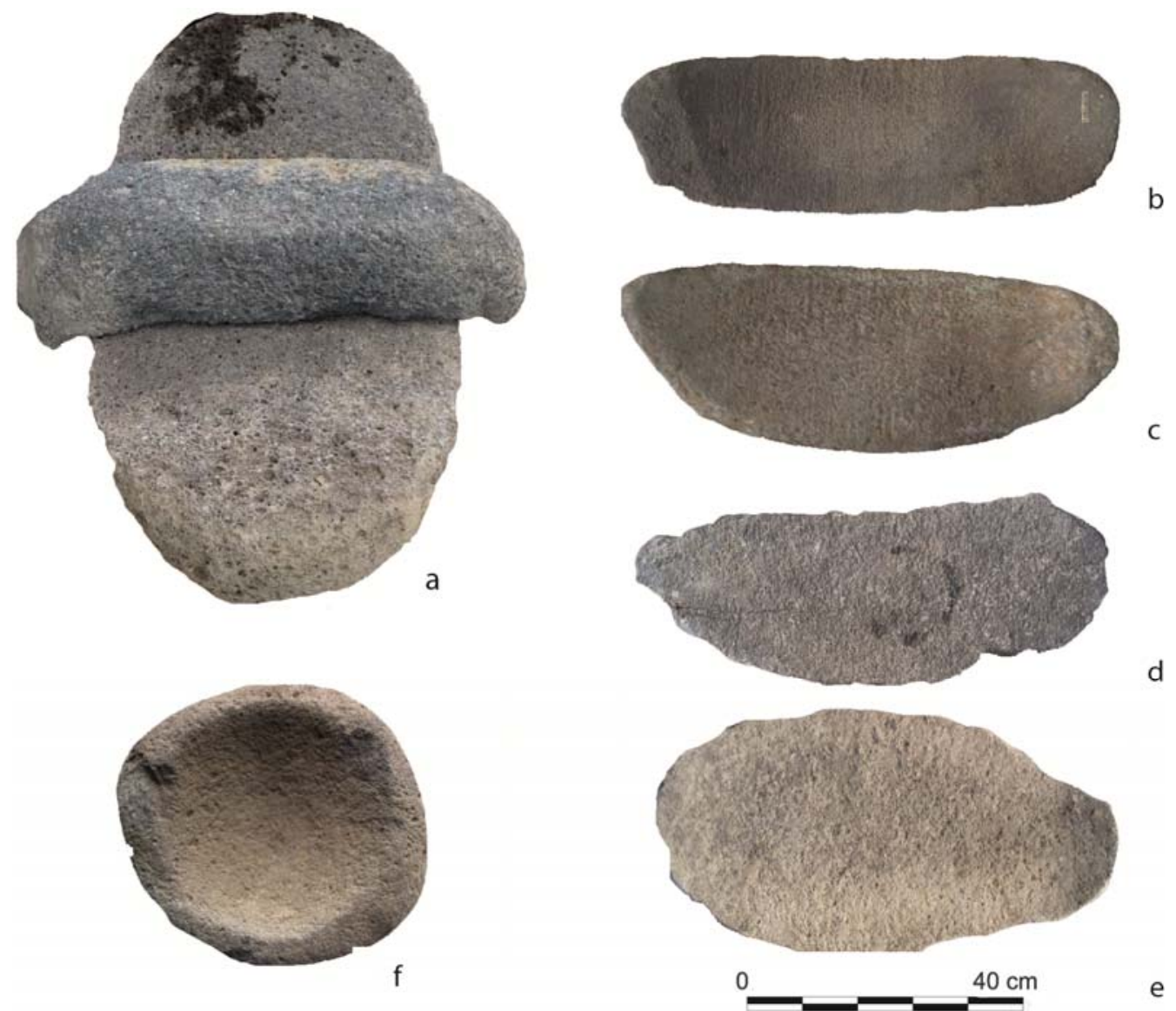

Figure 8. Early Bronze age macrolithic implements. a. example of complete grinding tools system with overlapping grinder from Mentesh tepe; Example of overlapping grinders from b-c. Kwartrelebi; d-e. Davati; f. small mortar from Davati (photographs by C. Hamon).

\subsubsection{Discussion}

The macrolithic implements from Kuro-Araxe contexts seem to be limited to a couple of types of tools and activities, especially grinding, pounding or crushing tools. This could be a direct consequence of the widespread diffusion of metal tools within the Kura-Araxe sphere. The appearance of a very identifiable type of grinder can be considered as a chronological and cultural marker of the Kura-Araxe culture and it is likely that these implements were produced by specialised craftsmen. This suggests that, instead of the hypothesis of an economy intensively orientated towards the exploitation of animal resources, we are looking at a situation where cereals remained the central component of Kura-Araxes food strategies. The second field in which macrolithic tools were intensively used is related to mining contexts. Different kinds of tools were used in the mining process: picks and hammers were used for the extraction stages while crushing tools were used for the processing of the rocks, copper or gold ores as well as salt. The characteristics of these implements suggest frequent episodes of use over a long period of time. Furthermore, the production of very well-finished tools requiring a significant investment of time and skill may indicate that mining activity had a special status within Kura-Araxe communities. 


\section{Synthesis}

\subsection{Long term evolution of grinding tools}

This initial overview of the long-term evolution of grinding tools allows us to make a number of observations. First of all, it must be stressed that similar raw material supply strategies were applied throughout the period. Since the first occupation levels of the Shulaveri-Shomu sites, vesicular basalts of high porosity were preferred for the manufacture of querns, while more diverse rock types (granites, sandstones, andesites) were selected for grinders. A proportion of the blanks took the form of large cobbles, retrieved from the main riverbeds (Hansen et al. 2013), but we cannot exclude the possibility that true extraction sites were also exploited, especially for the production of large Kura-Araxian grinding tools.

A clear evolution of grinding tools types is also apparent, from varied grinding motions employed during the Neolithic to more restrictive back-and-forth motions in the Kura-Araxe culture. The diversity of grinding systems and motions in the Neolithic, ranging from backand-forth to circular or multidirectional motions, seems to be linked to the great diversity of uses to which these tools were put: processing of cereals and other plants and grinding of minerals. While we observe a reduction in the number of grinding tool types in the Chalcolithic, the diversity of the tools seems to be related more to their duration of use, linked to the multiplication of short-term and specialised sites. This probably explains the opportunistic choice and low standardisation of the blanks which are evident for a large proportion of the grinding tools. However, it is during the Kura-Araxe period that the grinding tools become restricted to back-and-forth motions, with the emergence of long, overlapping grinders. This evolution seems to be accompanied by a progressive increase in the grinding surfaces, especially the grinder sizes, from the Neolithic to Early Bronze Age.

All these observations would seem to suggest an evolution toward greater specialisation in terms of function and materials being transformed by grinding tools, with a much greater emphasis on their use for cereal processing. Such functional specialisation would also have affected the production of these grinding tools, turned towards a higher level of standardisation.

\subsection{Towards a specialization of macrolithic tools for craft activities}

The use of ground stone tools for a wide range of craft activities is one of the major technological shifts characterising the Neolithic. In a context of technological renewal and of permanent settlements with a broad economic spectrum, macrolithic tools were used in numerous chaîne opératoires, including lithic debitage, the polishing of adzes, the manufacture of bone tools and ornaments and the processing of pigments. During the Chalcolithic, the macrolithic toolkit shows elements inherited from Late Neolithic contexts, together with a reduction of tools types, except for those used for crushing and pounding activities. This seems to be correlated to a shift in the technical system as well as in the economic diversification of the settlements themselves. The macrolithic toolkit becomes an indicator of the activities taking place in each settlement. The Majkop example is in itself significant, as it stresses the importance of the treatment of animal products within the economy of these populations, principally known through their burial practices. In addition, in the context of the emergence of metallurgy, crushing implements represent an increasing proportion within the assemblages: they constitute rare indicators of ore processing on major as well as secondary sites. This increasing impact of metallurgy development on the lithic toolkit is also perceptible through the emergence of sharpeners. Overall, macrolithic tools appear more opportunistic in the way in which they were produced but also used. This reduction in the activities represented within the macrolithic assemblage is even more evident 
during the Early Bronze Age. Macrolithic implements disappear from most of the fields of activity, except on mining sites and secondary workshops, where thousands of tools, including hammers, picks, grinding and pounding tools, were used for the processing of different rocks and ores. Within the Kura-Araxe culture, the use of macrolithic implements seems very much limited to a couple of activities.

\subsection{Regional specificities: the environmental and the cultural}

The study of macrolithic tools in the South Caucasus provides new elements to the discussion regarding the role played by contrasted ecological environment, mineral resource availability and cultural contexts in the economies of the populations evolving in the region between the 6th and the 3rd millennia BCE. In fact, the grinding tools types seem directly related to the nature and duration of the settlements, and by extension to the importance of agriculture and cereal consumption in the economies. The emergence of specialised sites possibly linked to the exploitation of mineral resources (ochre, ores, salt) since the Chalcolithic, but more clearly during the Early Bronze Age, led to the use of specialised macrolithic toolkits. However, in addition, part of the macrolithic equipment contributes to the definition of a common cultural background and regional specificities. During the Late Neolithic, a similar toolkit was shared by the populations in the Kura and Araxe regions. However regional specificities did arise. For example, the presence of pumice hand abraders and of ophiocalite polishers in the Ararat plain constitute a clear regional difference with the Kura valley assemblage (Badalyan et al. 2007; 2010); these specificities seem to be due to more intense links with the Anatolian and northern Mesopotamian spheres in the southern part of the South Caucasus. This would also explain the differences in composition between the Aratashen-Shulaveri-Shomu and the Mil Steppe macrolithic assemblages (Lyonnet et al. 2012). But the most striking example of the cultural significance of these implements is to be found in the distinctive Kuro-Araxe grinding tools. In itself, this standardized tool type raises questions regarding the role played by cereals in the dietary habits of Early Bronze Age cultures.

\section{Conclusion}

This study of the macrolithic assemblages from about 20 sites of the middle Kura Valley has allowed to better define the economies of the Late Neolithic to Early Bronze Age sites in the South Caucasus. It underlines the value of activity evidence, linked to the emergence of different major economic shifts, such as agriculture and cereal processing or metallurgy and ore processing. These implements also constitute markers of cultural unicity and regional specificities and thus contribute to discussions about the origins and development of the major culture of the South Caucasus in its regional context.

\section{Acknowledgements}

This work has been funded by several programs and institutions. First of all, I would like to thank the French Ministry of Foreign Affairs (Lavoisier post-doc program 2006) and our colleagues at the Georgian National Museum for their welcome: D. Lordkipanidze, Z. Makharadze, N. Grigolia, M. Jalabadze, E. Qoridze, M. Menabde, T. Meshveliani. I am also grateful to G. Mirtskhulava (Tbilisi Centre for Archaeological Science) and S. Hansen (Deutsche Archäeologisches Institut) who gave me access to the finds from Aruchlo I. The study of the Sioni macrolithic toolkits from the Aragvi valley would not have been possible without the collaboration of G. Chikovani, and G. Gogodjuri from the Centre for Archaeological Science in Tbilisi. The study of the macrolithic assemblage from Mentesh 
tepe was undertaken within the framework of the Boyuk Kezik program and the ANR-DFG Kura in Motion! (ANR-12-FRAL-0011) in collaboration with the Archaeological institute of Azerbaijan: my sincerest thanks to B. Lyonnet and F. Guliyev. Corrections of the English language has been proceeded by Mrs. Maria Rhoda Cronin-Allanic.

\section{References}

Akhundov, T. 2007, Site de migrants venus du Proche-Orient en Transcaucasie. In: Les cultures du Caucase (VIe-IIIe siècle avant notre ère). Leurs relations avec le ProcheOrient, (Lyonnet, B., Ed.), Editions Recherches sur les civilisations, Paris: p. 189-198. (in French) ("Site migrants from the Near East in Transcaucasia")

Arimura, M., Badalyan, R., Gasparyan, B. \& Chataigner, C. 2010, Current Neolithic Research in Armenia. NEO-LITHICS, 1(10): 77-85.

Badalyan, R., Lombard, P., Avetisyan, P., Chataigner, C., Chabot, J., Vila, E., Hovsepyan, R., Willcox, G. \& Pessin, H. 2007, New data on the Late Prehistory of the Southern Caucasus. The excavations at Aratashen (Armenia): Preliminary report. In: Les cultures du Caucase (VIe-IIIe siècle avant notre ère). Leurs relations avec le Proche-Orient, (Lyonnet, B., Ed.), Editions Recherches sur les civilisations, Paris: p. 37-61.

Badalyan, R., Harutyunyan, A., Chataigner, C., Le Mort, F., Chabot, J., Brochier, J.E., Balasescu, A., Radu, V. \& Hovsepyan, R. 2010, The settlement of AknashenKhatunarkh. A Neolithic site in the Ararat plain (Armenia): Excavation Results 20042009. $T \ddot{U} B A-A R, 13$ (2010): 185-218.

Chataigner, C., Badalyan, R. \& Arimura, M. 2014, The Neolithic of the Caucasus. Oxford Handbooks Online. Oxford University Press, Oxford, 34 p. doi:10.1093/oxfordhb/9780199935413.013.13

Chikovani, G. 1999, Shida-Kartli V-VIth millennium BC Ph.D [Shida-Kartli V-VIth millennium BC Ph.D]. Center for archaeological research publications, Tbilisi, $305 \mathrm{p}$.

Courcier, A., Bakhtiyar, J., Idriss, A., Farhad, G., Moritz, J., Lyonnet, B., Mukhtarov, N. \& Museibli, N. 2017, The ancient metallurgy in Azerbaijan from the end of the Neolithic to the Early Bronze Age (6th-3rd millennium BCE): an overview in the light of new discoveries and recent archaeometallurgical research. In: The Kura Projects. New Research on the Later Prehistory of the Southern Caucasus, (Helwing, B., Aliyev, T., Lyonnet, B., Guliyev, F., Hansen, S. \& Mirtskhulava, G., Eds), Archäologie in Iran und Turan 16: 25-35.

Djavakhishvili, A. 1998, Ausgrabungen in Bereekldebi (Shida-Kartli). Georgica, 21: 7-20. (in German) ("Excavations in Bereekldebi (Shida-Karlti")

Djavakhishvili, A. 1973, Строительное дело и архитектура поселений Южного Кавказа $V$-III mbıc. до н.э., Center for archaeological research publications, Tbilisi. (in Russian) ("Rules of architecture of the South Caucasus V-IIIth before our era")

Dubreuil, L. 2004, Long-term trends in Natufian subsistence: a use-wear analysis of ground stone tools. Journal of Archaeological Science, 31: 1613-1629. doi:10.1016/j.jas.2004.04.003

Guliyev, F. \& Nishiaki, Y. 2014, Excavations at the neolithic settlement of Göytepe, west Azerbaijan, 2010-2011. In: Proceedings of the 8th International Congress on the Archaeology of the Ancient Near East, Vol. 2, (Bielinski, P., Gawlikowski, M., 
Kolinski, R., Lawecka, D., Soltysiak, A., \& Wygnanska, Z., Eds.), Harrassowitz, Wiesbaden: p. 3-16.

Hamon, C. 2007, Modes de subsistance et activités dans le Chalcolithique du Caucase nord : étude fonctionnelle des outils en pierre de la culture de Maïkop, In: Les cultures du Caucase (VIe-IIIe siècle avant notre ère). Leurs relations avec le Proche-Orient, (Lyonnet, B., Ed.), Editions Recherches sur les civilisations, Paris: p. 189-198. (in French) ("Subsistance and activities in north Caucasian Chalcolithic: functional studies of stone tools from Majkop culture")

Hamon, C. 2008a, From Neolithic to Chalcolithic in the Southern Caucasus: Economy and macrolithic implements from Shulaveri-Shomu sites of Kwemo-Kartli (Georgia). Paléorient 34(2): 85-136. doi:10.3406/paleo.2008.5258

Hamon, C. 2008b, Functional analysis of stone grinding and polishing tools from the earliest Neolithic of north-western Europe. Journal of Archaeological Science, 35: 1502-1520. doi:10.1016/j.jas.2007.10.017

Hamon, C., Jalabadze, M., Agapishvili, T., Baudouin, E., Koridze, E. \& Messager, E. 2016, Gadachrili Gora: Architecture and organisation of a Neolithic settlement in the middle Kura Valley (6th millennium BC, Georgia). Quaternary International, 395: 154-169. doi:10.1016/j.quaint.2015.01.055

Hamon, C. 2016, Salt from Duzdaği (Nakhchivan, Azerbaijan): tools, techniques and organisation at a mining site in the Caucasus from the $5^{\text {th }}$ to $3 \mathrm{rd}$ millennium BC. Journal of Field Archaeology, 41(4): 510-528. doi:10.1080/00934690.2016.1201615

Hansen S., Mirtskhulava G. \& Bastert-Lamprichs K. 2013, Neolithic settlements of the 6th millennium $\mathrm{BC}$ in the southern Caucasus. In: Interpreting the Late Neolithic of Upper Mesopotamia, (Nieuwenhuyse, O. P., Bernbeck, R., Akkermans, P.M.M.G. \& Rogasch, J., Eds.), Brepols, Turnhout: p. 387-396.

Kiguradze, T. 1986, Neolithische Siedlungen von Kvemo-Kartli, Georgien. Materialen zur Allgemeinen und Vergleichenden Archäologie Vol. 29, C.H. Beck, München, 117 p. (in German) ("The neolithic sites from Kvemo-Kartli, Georgia")

Kiguradze, T. \& Sagona, A. 2003, On the origins of the Kura-Araxes cultural complex. In: Archaeology in the Borderlands. Investigations in Caucasia and beyond, (Smith, A.T. \& Rubinson, K.S., Eds.). Cotsen Institute of Archaeology Monograph Vol. 47, University of California, Los Angeles: p. 38-94.

Kushnareva, K. 1997, The southern Caucasus in Prehistory. Stages of cultural and socioeconomic development from the 8th to the 2nd millennium BC, translated by H.N. Michael. University Museum Monograph Vol. 99, University of Pennsylvania, Philadelphia: 279 p.

Lyonnet, B., (Ed.) 2007, Les cultures du Caucase (VIe-IIIe millénaires avant notre ère). Leurs relations avec le Proche-Orient. Editions recherches sur les civilisations, Paris, 295 p. (in French) ("The cultures of Caucasus ( $7^{\mathrm{e}}-3$ rd millenium before Christ). Their relation with the Near East").

Lyonnet, B. 2007, La culture de Maïkop, la Transcaucasie, l'Anatolie orientale et le ProcheOrient: relations et chronologie. In : Les cultures $d u$ Caucase (VIe-IIIe siècle avant notre ère). Leurs relations avec le Proche-Orient, (Lyonnet, B., Ed.), Editions Recherches sur les civilisations, Paris: p. 189-198. (in French) ("The Majkop culture, Transcaucasia, eastern Anatolia and the Near East: relations and chronologies"). 
Lyonnet, B., Guliev, F., Helwing, B., Aliyev, T., Hansen S. \& Mirtskhulava, G. (Eds.) 2012, Ancient Kura 2010-2011: The first two seasons of joint field work in the southern Caucasus. Archäologische Mitteilungen aus Iran und Turan, 44: 1-190.

Marro, C., Bakhshaliyev, V. \& Ashurov, S. 2011, Excavations at Ovçular Tepesi (Nakhchivan, Azerbaijan). Second preliminary report: the 2009-2010 seasons. Anatolia Antiqua, 19: 53-100. doi:10.3406/anata.2011.1089

Niebieridze, L. 1986, Ранный Ступень Звездазападноза Кавказ Скойран Земледельческой культура. Mietsniereba, Tbilisi. 124 p. (in Russian) ("The development of agriculture in Western Caucasus").

Nishiaki, Y, Guliyev, F. \& Kadowaki, S. 2015, Chronological contexts of the earliest Pottery Neolithic in the South Caucasus: Radiocarbon dates for Goytepe and Haci Elamxanli Tepe, Azerbaijan. American Journal of Archaeology, 119: 279-294. doi:10.3764/aja.119.3.0279

Palumbi, G. \& Chataigner, C. 2014, The Kura-Araxes culture from the Caucasus to Iran, Anatolia and the Levant: between unity and diversity. A synthesis. Paléorient, 40(2): 247-260. doi:10.3406/paleo.2014.5645

Sagona, A. 2014, Rethinking the Kuro-Araxes Genesis. Paléorient, 40(2): 131-154. doi:10.3406/paleo.2014.5634

Stöllner, T., Craddock, B., Gambaschidze, I., Gogotchuri, G., Hauptmann, A., Hornschuch, A., Klein, F., Löffler, I., Mindiashwili, G., Murwanidze, B., Senczek, S., Schaich, M., Steffens, G., Tamasashvili, K. \& Timberlake, S. 2014, Gold in the Caucasus: New research on gold extraction in the Kura-Araxes Culture of the 4th millennium BC and early 3rd millennium B.C.. In: Metalle der Macht, (Meller, H., Pernicka, E. \& Risch, R., Eds.), Tagungen des landesmuseums für vorgeschichte, Halle: p. 71-110.

Tamazashvili, K. 2014, Prehistoric mining implements from Georgia. Mtsignobari, Tbilisi, $140 \mathrm{p}$.

Wright, K. 1992, A Classification System for Ground Stone Tools from the Prehistoric Levant. Paléorient, 18(2): 53-81. doi:10.3406/paleo.1992.4573 